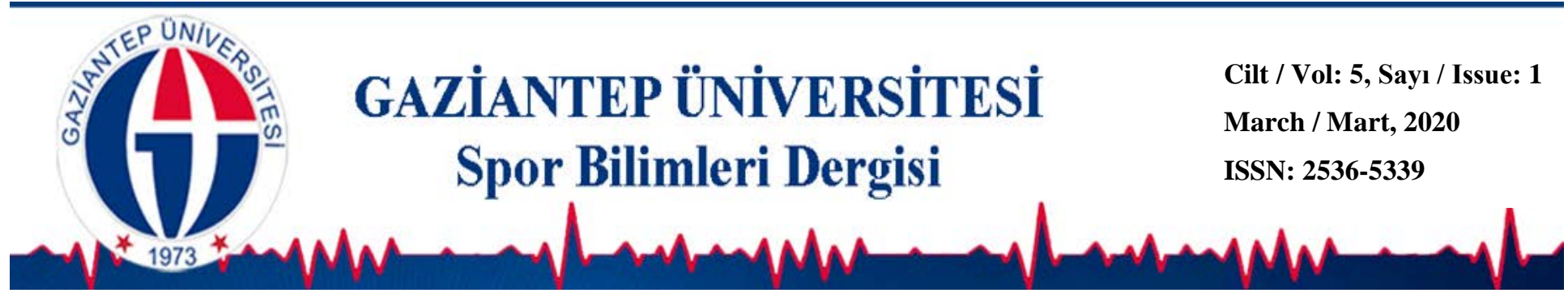

\title{
Okul Sporlarına Katılan ve Katılmayan Ortaöğretim Öğrencilerinin, Fiziksel Uygunluklarının Eurofit Test Bataryası İle Karşılaştırılması
}

\author{
Mehmet Bülent ASMA ${ }^{1 *}$ (iD $\quad$ Mehmet Ali IŞIK (D) \\ ${ }^{1}$ Yüzüncüyıl Üniversitesi, Beden Eğitimi ve Spor Yüksekokulu, VAN
}

DOI: $10.31680 / g a u n j s s .685575$

Orijinal Makale / Original Article

Geliş Tarihi / Received: 06.02.2020 Kabul Tarihi / Accepted: 24.02.2020 Yayın Tarihi / Published: 23.03.2020

Öz

Bu araştırma: 17-18 yaş ortaöğretim öğrencilerinin fiziksel uygunluklarının EUROFiT test bataryası ile ölçülmesi sonrası spor yapma alışkanlığı olan lisansı ve lisanssız öğrenciler arasındaki farkları incelemek için yapılmıştır..Verilerin toplanması aşamasında EUROFiT test bataryası kullanılmıştır. İstatistik analizleri SPSS 24 paket program kullanılarak yapıldı. Fiziksel uygunluk ölçümleri sonucu aktif spor yapan kız öğrencilerin otur-eriş, mekik testi, bükülü kol asılma testi, durarak uzun atlama ve 20 metre mekik koşusu değerleri aktif spor yapmayan kız öğrencilere göre anlamlı olarak daha yüksek bulunurken, 10×5 mekik koşu testi, flamingo denge testi ve disklere dokunma testi değerleri aktif spor yapmayan kız öğrencilere göre anlamlı olarak daha düşük bulunmuştur $(p<0.05)$. Boy uzunluğu, vücut ağırlığı, vücut kitle indeksi ve el pençe kuvveti değerleri arasında aktif spor yapan kız öğrenciler ile aktif spor yapmayan kız öğrenciler arasında anlamlı bir farklılık bulunamamıştır. ( $p>0.05$ ).Aktif spor yapan erkek öğrencilerin durarak uzun atlama, 20 metre mekik koşu testi, mekik ve bükülü kol asılma değerleri aktif spor yapmayan erkek öğrencilere göre anlamlı olarak daha yüksek olduğu bulunurken 10×5 mekik koşu testi ve disklere dokunma test değerleri aktif spor yapmayan erkek öğrencilere göre anlamlı olarak daha düşük bulunmuştur $(p<0.05)$. Boy uzunluğu, vücut ağırlığı, vücut kitle indeksi, flamingo denge testi, otur-eriş ve el pençe kuvveti değerleri arasında aktif spor yapan erkek öğrenciler ile yapmayan erkek öğrenciler arasında anlamlı bir farklılık bulunamamıştır ( $p>0.05$ ). Sonuç olarak 15-18 yaş aktif spor yapan erkek ve kız öğrencilerin fiziksel uygunluk test bataryası sonuçları aktif spor yapmayanlara oranla daha yüksek bulunmuştur. Bu durum spor yapmanın fiziki gelişimi desteklediğini göstermektedir. Eurofit test bataryasının; sporcuların performansının belirlenmesi, velilere çocuklarının gelişimi hakkında bilgi vermesi, eğitmenlere de yetenek seçiminde yol gösterici olmasından dolayı kullanılması fayda sağlayacaktır.

AnahtarKelimeler: Eurofit, fiziksel uygunluk, antropometri, ortaöğretim, beceri, test bataryası.

\footnotetext{
* Sorumlu Yazar: Mehmet Bülent ASMA

*Bu çalışma Yüksek Lisans tezinden üretilmiştir.
}

E-mail: mbulentasma@yyu.edu.tr 


\title{
Comparison of Physical Fitness of the High School Students Participating and Not Participating in School Sports Using the Eurofit Test Battery
}

\begin{abstract}
This study was carried out to examine the differences between licensed and unlicensed students who have a habit of doing sports after the measurement of physical fitness of high school students aged 15-18 with EUROFIT test battery. EUROFIT test battery was used for data collection. Statistical analyzes were performed by SPSS 24 package program. As a result of physical fitness measurements, while sit-and reach test, sit-up test, bent-arm hang test, standing broad jump test and $20 \mathrm{~m}$ shuttle run test values of female students engaged in active sports were found to be significantly higher than female students who did not have active sports; $10 \times 5 \mathrm{~m}$ agility shuttle run test, flamingo balance test and, plate tapping test values were found to be significantly lower than those of active female students $(p<0.05)$. No meaningful difference was found between female students engaged in active sports and non-engaged in active sports for height, body weight, body mass index and handgrip strenght test values. ( $p>0.05$ ). While active sportsmen's standing broad jump test, 20 m shuttle run test, sit-up test and bentarm hang test values were found to be significantly higher than the males who did not engage in active sports; $10 \times 5$ shuttle running test and plate tapping test values were found to be significantly lower than those who did not engage in active sports ( $p$ 0.05). There was no meaningful difference of height, body weight, body mass index, flamingo balance test, sit-and reach test and handgrip strenght test values ( $p>0.05)$ between male students who do active sports and who do not do active sports. As a result, physical fitness test battery results of boys and girls who have active sports between the ages of 15-18 were found to be higher than those who did not. This shows that sporting supports physical development. Use of Eurofit test battery will be beneficial to determine the performance of the athletes, to inform the parents about the development of their children and to use the instructors as a guide in the selection of talent.
\end{abstract}

Keywords: Eurofit, physicalfitness, anthropometry, highschool, skill, test battery

\section{Giriş}

Fiziksel uygunluk genel anlamda aşırı yorgunluk olmaksızın kişinin fiziksel, fizyolojik ve psikolojik olarak iyi hissetmesi ile birlikte günlük aktiviteleri başarma yeteneğidir. Çağımızda fiziksel uygunluğun ölçülmesi bir zorunluluk haline gelmiş olup bu amaçla geliştirilen birçok test bulunmaktadır. Fiziksel uygunluk testleri, bedensel yeterlilik gerektiren alanlarda seçim yapılması ve büyük kitlelerin sağık ile ilgili fiziki yeterliliklerinin saptanması amacıyla günümüzde sıkça kullanılmaktadır. Zaman içinde doğan intiyaçlar neticesinde fiziksel uygunluk testleri performans ve sağlıkla ile ilgili fiziksel uygunluk testleri olarak ayrışmıştır. Performans ile ilgili fiziksel uygunluk testleri spor liseleri giriş sınavları, üniversitelerin spor ile ilgili alanları, itfaiye, polis ve askeri sınavlara girişte sık kullanılmaktadır. Sağık ile ilgili fiziksel uygunluk testleri sağlıklı ve kaliteli bir yaşam sürdürebilmek ve toplumların sağık politikalarına yön vermek amacıyla kullanılmaktadır (Kayıhan ve Ersöz, 2010).

Sağlıkla ile ilgili fiziksel uygunluk, vücudun fonksiyonel kapasitesini arttıran bileşenlerden oluşur. Fiziksel uygunluk seviyesinin belirlenmesinde; kas kuvveti ve dayanıklıı̆ı, esneklik, kalp ve solunum sisteminin dayanıklıığı ve vücut kompozisyonu değerlendirilir. Test uygulanan kişiye bu değerlendirmeye uygun bir egzersiz programı verilir. Beceri ile ilgili fiziksel uygunluk, sağlıkla ilgili fiziksel uygunluk bileşenlerinin yanı sıra çeviklik, hız, güç, reaksiyon zamanı, denge ve 
Asma, MB., Iş̧k, MA. (2020). Okul Sporlarına Katılan ve Katılmayan Ortaöğretim Öğrencilerinin Fiziksel Uygunluklarının Eurofit Test Bataryası ile Karşılaştırılması. Gaziantep Üniversitesi Spor Bilimleri Dergisi, 5(1), 10-26.

koordinasyondan oluşmaktadır. Spor ile ilgili fiziksel uygunluk seviyesinin belirlenmesinde kişinin yaptığı veya yapmak istediği spora yönelik değerlendirmeler yapılır (Baltacı ve Düzgün, 2008).

Bununla birlikte çocuklara uygulanan fiziksel ve fizyolojik testlerin amacı, ergenlik dönemindeki bireylerin antrene edilebilirliklerini incelemek, testlerin büyüme, gelişme ve sağlık üzerindeki etkileri ışığında yol gösterici olmasını sağlamaktır (Pekel ve ark., 2006).

Genel bir bakış açısıyla, Eurofit test bataryaları ise bedensel yeteneklerinin hangi boyutlarda olduğunu ölçmeye yardımcı olabilecek unsurları kapsamaktadır. Eurofit test bataryaları, çocukların kişiliklerinin keşfedilebilmesi ve sorumluluk duygularının gelişebilmesi için düşünülmüş olmakla beraber 6 ile 18 yaşlar arası gruplara başarılı bir biçimde uygulanmaktadır (Demir, 2001).

\section{Yöntem}

\section{Araştırmanın Amacı}

Okul sporlarına katılan ve katılmayan ortaöğretim öğrencileri arasındaki fiziksel uygunluk farklarının saptanması, elde edilen sonuçların incelenmesi ve sonuçlarına göre spora yönlendirmenin öneminin vurgulanması hedeflenmiştir. Böylece spor yapma alışkanlığı olan, sosyal, girişken ve sağlıklı gençlerin sayısının artıııması hedeflenmiştir.

\section{Evren ve Örneklem}

Çalışmaya Van ilindeki 17-18 yaş grubu öğrenciler ile Van ili Edremit ilçesinde bulunan 2 Meslek Lisesi 2 Anadolu Lisesi 1 Özel Okul ve 1 Fen Lisesinden oluşan 6 ortaöğretim kurumunda okuyan 36 kız 114 erkek olmak üzere 150 kişi katılmıştır. Katıımcıların 22 kız 53 erkek olmak üzere toplamda 75 kişisini okul sporlarına katılan lisanslı öğrenciler, 14 kız 61 erkek öğrenci olmak üzere lisanslı ve aktif olarak spor yapmayan sadece beden eğitimi dersine katılan herhangi bir sağlık problemi olmayan öğrenciler oluşturmaktadır.

Bu çalışma için Yüzüncü Yıl Üniversitesi Sosyal ve Beşeri Bilimleri Etik Kurulu'ndan izin alınmışıı. Çalışmanın uygulanması için Yüzüncü Yıl Üniversitesi aracılığıyla Van İ Milli Eğitim ve Edremit ilçesinden gerekli izinler alınmıştır. Öğrencilerin yaşları, aktif spor yapıp yapmama durumları, hangi branşı yaptıkları 
Asma, MB., Iş̧1k, MA. (2020). Okul Sporlarına Katılan ve Katılmayan Ortaöğretim Öğrencilerinin Fiziksel Uygunluklarının Eurofit Test Bataryası ile Karşılaştırılması. Gaziantep Üniversitesi Spor Bilimleri Dergisi, 5(1), 10-26.

"Gönüllü Test Takip Formu"na kaydedilmiştir. Gönüllü öğrencilere testlerin başlangıcından önce uygulanacak yapılacak ölçümler ve testler hakkında bilgi verilmiş, kullanılacak malzeme ve materyallerin tanıtımı yapılmıştır. Testlerin uygulanmasına başlanmadan öğrenci ve velilere "Gönüllü Bilgilendirme ve Onay Formu" imzalatılış̧tır.

\section{Verilerin Toplanması}

Fiziki uygunluk test ölçümü Eurofittest bataryası ile yapılmıştır. Test bataryası içinde yer alan testler: flamingo denge testi, disklere dokunma testi, otur eriş testi, durarak uzun atlama testi, el pençe kuvvet testi, mekik testi, bükülü kol asılma testi, 10x5 metre mekik koşu testi, 20 metre mekik koşu testi ve antropometrik ölçümler kullanılmıştır. Uygulanan testlerde Eurofit test protokolü izlenmiştir. Katıımcı testlerin tümünü spor giysileriyle yapmıştır. Tüm testler iyi havalandırılmış bir spor salonunda yapılmış, koşu ve atlama testleri kaygan olmayan bir zemin üzerinde uygulanmıştır. Motor test bataryası bir dairesel sistem olup, belli bir sıraya göre uygulanmıştır. Test sırasında katıımcının testi daha iyi yapabilmesi için motive edilmesi çok önemlidir. Katıımcı ölçülen değişkene göre eksiksiz, hızlı ve daha iyi bir performans sergilemesi yönünde teşvik edilmiştir.

\section{Verilerin analizi}

Araştırmada Normallik sınamalarından olan Kolmogorov-Smirnov testi uygulandı. Verilerin analizinde gruplar arası ortalamalarda ki farkın anlamlılık tespiti için normal dağılım gösteren değişkenlere bağımsız $\mathrm{t}$ testleri (Independent $\mathrm{t}$-test), göstermeyen değişkenlere Mann-Whitney $U$ testi yapıldı. Anlamlılık değeri $p \leq 0,05$ olarak kabul edildi. Katılımcıların ölçülen ve test edilen değerlerinin ortalaması ve standart sapması (SS) hesaplandı. Elde edilen her sonucun maksimum ve minimum değeri gösterildi. Verilerinin istatistiksel analizinde SPSS. 24 paket programı kullanıldı. 
Asma, MB., Işık, MA. (2020). Okul Sporlarına Katılan ve Katılmayan Ortaöğretim Öğrencilerinin Fiziksel Uygunluklarının Eurofit Test Bataryası ile Karşılaştırılması. Gaziantep Üniversitesi Spor Bilimleri Dergisi, 5(1), $10-26$.

\section{Bulgular}

Tablo 1. 17-18 Yaş Eurofit Kız T-test ve Mann Whitney U Testi Sonuçları

\begin{tabular}{|c|c|c|c|c|c|c|c|}
\hline Testler & Gruplar & $\mathbf{N}$ & Min. & Mak. & Ort. & S.S & p \\
\hline \multirow[b]{2}{*}{ Boy Uzunluğu (cm) } & $\begin{array}{l}\text { Aktif Spor } \\
\text { Yapan }\end{array}$ & 22 & 150 & 168 & $\begin{array}{l}160,2 \\
3\end{array}$ & 5,35 & \multirow[b]{2}{*}{$P>0,05$} \\
\hline & $\begin{array}{l}\text { Aktif Spor } \\
\text { Yapmayan }\end{array}$ & 14 & 148 & 174 & $\begin{array}{l}158,3 \\
6\end{array}$ & 7,00 & \\
\hline \multirow{2}{*}{ Vücut Ağırlığı (kg) } & $\begin{array}{l}\text { Aktif Spor } \\
\text { Yapan }\end{array}$ & 22 & 45,00 & 72,00 & 54,68 & 7,20 & \multirow{2}{*}{$P>0,05$} \\
\hline & $\begin{array}{l}\text { Aktif Spor } \\
\text { Yapmayan }\end{array}$ & 14 & 42,00 & 73,00 & 54,00 & 8,99 & \\
\hline \multirow{2}{*}{ Vücut Kitle İndeksi } & $\begin{array}{l}\text { Aktif Spor } \\
\text { Yapan }\end{array}$ & 22 & 17,85 & 28,13 & 21,33 & 2,86 & \multirow{2}{*}{$P>0,05$} \\
\hline & $\begin{array}{l}\text { Aktif Spor } \\
\text { Yapmayan }\end{array}$ & 14 & 17,48 & 27,82 & 21,49 & 3,05 & \\
\hline \multirow{2}{*}{$\begin{array}{l}\text { Flamingo Denge Testi } \\
\text { (hata sayısı) }\end{array}$} & $\begin{array}{l}\text { Aktif Spor } \\
\text { Yapan }\end{array}$ & 22 & 6 & 17 & 10,86 & 3,40 & \multirow[b]{2}{*}{$P>0,05$} \\
\hline & $\begin{array}{l}\text { Aktif Spor } \\
\text { Yapmayan }\end{array}$ & 14 & 5 & 24 & 12,64 & 5,24 & \\
\hline \multirow{2}{*}{$\begin{array}{l}\text { Disklere Dokunma } \\
\text { Testi (sn) }\end{array}$} & $\begin{array}{l}\text { Aktif Spor } \\
\text { Yapan }\end{array}$ & 22 & 6,59 & 11,62 & 8,94 & 1,54 & \multirow{2}{*}{$P<0,05$} \\
\hline & $\begin{array}{l}\text { Aktif Spor } \\
\text { Yapmayan }\end{array}$ & 14 & 7,72 & 12,20 & 10,12 & 1,18 & \\
\hline \multirow{2}{*}{ Otur-Eriş Testi (cm) } & $\begin{array}{c}\text { Aktif Spor } \\
\text { Yapan }\end{array}$ & 22 & 22 & 37 & 31,05 & 4,17 & \multirow{2}{*}{$P<0,05$} \\
\hline & $\begin{array}{l}\text { Aktif Spor } \\
\text { Yapmayan }\end{array}$ & 14 & 9 & 35 & 24,36 & 6,83 & \\
\hline \multirow{2}{*}{$\begin{array}{l}\text { Durarak Uzun Atlama } \\
\text { (cm) }\end{array}$} & $\begin{array}{l}\text { Aktif Spor } \\
\text { Yapan }\end{array}$ & 22 & 121 & 222 & $\begin{array}{l}160,8 \\
2\end{array}$ & 22,73 & \multirow{2}{*}{$P>0,05$} \\
\hline & $\begin{array}{l}\text { Aktif Spor } \\
\text { Yapmayan }\end{array}$ & 14 & 94 & 186 & $\begin{array}{l}147,1 \\
4\end{array}$ & 25,27 & \\
\hline \multirow{2}{*}{ EI Pençe Kuvveti (kg) } & $\begin{array}{l}\text { Aktif Spor } \\
\text { Yapan }\end{array}$ & 22 & 24,10 & 34,70 & 29,84 & 2,98 & \multirow{2}{*}{$P>0,05$} \\
\hline & $\begin{array}{l}\text { Aktif Spor } \\
\text { Yapmayan }\end{array}$ & 14 & 19,00 & 38,60 & 29,47 & 5,80 & \\
\hline \multirow{2}{*}{$\begin{array}{l}\text { Mekik Testi (tekrar } \\
\text { sayısı) }\end{array}$} & $\begin{array}{c}\text { Aktif Spor } \\
\text { Yapan }\end{array}$ & 22 & 2 & 28 & 17,50 & 5,32 & \multirow{2}{*}{$P<0,05$} \\
\hline & $\begin{array}{l}\text { Aktif Spor } \\
\text { Yapmayan }\end{array}$ & 14 & 5 & 24 & 13,50 & 4,99 & \\
\hline \multirow{2}{*}{$\begin{array}{l}\text { Bükülü Kol Asılma } \\
\text { (sn) }\end{array}$} & $\begin{array}{l}\text { Aktif Spor } \\
\text { Yapan }\end{array}$ & 22 & 2 & 33,84 & 8,58 & 8,56 & \multirow{2}{*}{$P>0,05$} \\
\hline & $\begin{array}{l}\text { Aktif Spor } \\
\text { Yapmayan }\end{array}$ & 14 & 1 & 12,28 & 4,35 & 3,85 & \\
\hline \multirow{2}{*}{$\begin{array}{l}\text { 10x5 Mekik Koşusu } \\
\text { Testi (sn) }\end{array}$} & $\begin{array}{l}\text { Aktif Spor } \\
\text { Yapan }\end{array}$ & 22 & 17,00 & 22,81 & 18,82 & 1,36 & \multirow{2}{*}{$P<0,05$} \\
\hline & $\begin{array}{l}\text { Aktif Spor } \\
\text { Yapmayan }\end{array}$ & 14 & 18,99 & 26,75 & 20,75 & 2,15 & \\
\hline \multirow[t]{2}{*}{$\begin{array}{l}20 \text { Metre Mekik Koşu } \\
\text { Testi (tekrar sayısı) }\end{array}$} & $\begin{array}{l}\text { Aktif Spor } \\
\text { Yapan }\end{array}$ & 22 & 14 & 74 & 36,73 & 17,69 & \multirow[b]{2}{*}{$P>0,05$} \\
\hline & $\begin{array}{l}\text { Aktif Spor } \\
\text { Yapmayan }\end{array}$ & 14 & 9 & 63 & 33,29 & 19,80 & \\
\hline
\end{tabular}

17-18 yaşaktif spor yapan kız öğrencilerin otur-eriş ve mekik testi değerleri aktif spor yapmayan kız öğrencilere göre anlamlı olarak daha yüksek bulunurken, $10 \times 5$ mekik koşu testi ve disklere dokunma testi değerleri aktif spor yapmayan kız öğrencilere göre anlamlı $(p<0,05)$ olarak daha düşük bulunmuştur. Boy uzunluğu, 
Asma, MB., Işık, MA. (2020). Okul Sporlarına Katılan ve Katılmayan Ortaöğretim Öğrencilerinin Fiziksel Uygunluklarının Eurofit Test Bataryası ile Karşılaştırılması. Gaziantep Üniversitesi Spor Bilimleri Dergisi, 5(1), 10-26.

vücut ağırlığı, vücut kitle indeksi, flamingo denge testi, durarak uzun atlama, el pençe kuvveti, bükülü kol asılma ve 20 Metre mekik koşu testi değerleri arasında aktif spor yapan kız öğrenciler ile aktif spor yapmayan kız öğrenciler arasında anlamlı $(p>0,05)$ bir farklılık bulunamamıştır.

Tablo 2.17-18 Yaş Eurofit Erkek T-test ve Mann Whitney U Test Sonuçları

\begin{tabular}{|c|c|c|c|c|c|c|c|}
\hline Testler & Gruplar & $\mathbf{N}$ & Min. & Maks & Ortalama & S.S & $\begin{array}{l}\text { İstatistiki } \\
\text { anlam }\end{array}$ \\
\hline \multirow{2}{*}{$\begin{array}{l}\text { Boy } \\
\text { Uzunluğu } \\
\text { (cm) }\end{array}$} & Aktif Spor Yapan & 53 & 162 & 194 & 173,28 & 7,26 & \multirow[b]{2}{*}{$P>0,05$} \\
\hline & Aktif Spor Yapmayan & 61 & 154 & 185 & 172,82 & 6,52 & \\
\hline \multirow{2}{*}{$\begin{array}{l}\text { Vücut } \\
\text { Ağırlığı (kg) }\end{array}$} & Aktif Spor Yapan & 53 & 50,00 & 88,00 & 65,32 & 8,64 & \multirow{2}{*}{$P>0,05$} \\
\hline & Aktif Spor Yapmayan & 61 & 48,00 & 89,00 & 64,03 & 9,70 & \\
\hline \multirow{2}{*}{$\begin{array}{l}\text { Vücut Kitle } \\
\text { İndeksi }\end{array}$} & Aktif Spor Yapan & 53 & 16,33 & 30,09 & 21,78 & 2,82 & \multirow{2}{*}{$P>0,05$} \\
\hline & Aktif Spor Yapmayan & 61 & 16,30 & 28,09 & 21,38 & 2,53 & \\
\hline \multirow{2}{*}{$\begin{array}{l}\text { Flamingo } \\
\text { Denge Testi } \\
\text { (hata sayısı) }\end{array}$} & Aktif Spor Yapan & 53 & 5 & 23 & 11,55 & 4,38 & \multirow[b]{2}{*}{$P>0,05$} \\
\hline & Aktif Spor Yapmayan & 61 & 6 & 26 & 12,59 & 4,96 & \\
\hline \multirow{2}{*}{$\begin{array}{l}\text { Disklere } \\
\text { Dokunma } \\
\text { Testi (sn) }\end{array}$} & Aktif Spor Yapan & 53 & 5,00 & 12,25 & 8,56 & 1,48 & \multirow[b]{2}{*}{$P>0,05$} \\
\hline & Aktif Spor Yapmayan & 61 & 6,34 & 15,00 & 9,08 & 1,89 & \\
\hline \multirow{2}{*}{$\begin{array}{l}\text { Otur-Eriş } \\
\text { Testi (cm) }\end{array}$} & Aktif Spor Yapan & 53 & 2 & 40 & 24,47 & 8,73 & \multirow{2}{*}{$P>0,05$} \\
\hline & Aktif Spor Yapmayan & 61 & 5 & 37 & 22,93 & 7,23 & \\
\hline \multirow{2}{*}{$\begin{array}{l}\text { Durarak } \\
\text { Uzun } \\
\text { Atlama (cm) }\end{array}$} & Aktif Spor Yapan & 53 & 112 & 267 & 208,40 & 31,04 & \multirow[b]{2}{*}{$\mathrm{P}<0,05$} \\
\hline & Aktif Spor Yapmayan & 61 & 147 & 237 & 193,28 & 21,95 & \\
\hline \multirow{2}{*}{$\begin{array}{l}\text { El Pençe } \\
\text { Kuvveti (kg) }\end{array}$} & Aktif Spor Yapan & 53 & 34,60 & 63,00 & 46,64 & 6,57 & \multirow{2}{*}{$P>0,05$} \\
\hline & Aktif Spor Yapmayan & 61 & 32,00 & 64,00 & 44,20 & 6,85 & \\
\hline \multirow{2}{*}{$\begin{array}{l}\text { Mekik Testi } \\
\text { (tekrar } \\
\text { sayısı) }\end{array}$} & Aktif Spor Yapan & 53 & 12 & 33 & 22,77 & 4,75 & \multirow[b]{2}{*}{$P>0,05$} \\
\hline & Aktif Spor Yapmayan & 61 & 14 & 30 & 21,57 & 3,77 & \\
\hline \multirow{2}{*}{$\begin{array}{l}\text { Bükülü Kol } \\
\text { Asılma (sn) }\end{array}$} & Aktif Spor Yapan & 53 & 6,00 & 72,00 & 35,92 & 16,91 & \multirow{2}{*}{$P>0,05$} \\
\hline & Aktif Spor Yapmayan & 61 & 4,00 & 61,69 & 34,45 & 13,91 & \\
\hline \multirow{2}{*}{$\begin{array}{l}\text { 10x5 Mekik } \\
\text { Koşusu } \\
\text { Testi (sn) }\end{array}$} & Aktif Spor Yapan & 53 & 13,63 & 20,00 & 16,69 & 1,29 & \multirow[b]{2}{*}{$P<0,05$} \\
\hline & Aktif Spor Yapmayan & 61 & 15,02 & 20,68 & 17,44 & 1,36 & \\
\hline \multirow{2}{*}{$\begin{array}{l}20 \text { Metre } \\
\text { Mekik Koşu } \\
\text { Testi (tekrar } \\
\text { sayısı) }\end{array}$} & Aktif Spor Yapan & 53 & 10 & 130 & 71,79 & 28,86 & \multirow[b]{2}{*}{$P<0,05$} \\
\hline & Aktif Spor Yapmayan & 61 & 16 & 125 & 56,41 & 25,27 & \\
\hline
\end{tabular}

17-18 yaşaktif spor yapan erkek öğrencilerin durarak uzun atlama ve 20 Metre mekik koşu testi değerleri aktif spor yapmayan erkek öğrencilere göre anlamlı olarak daha yüksek olduğu bulunurken $10 \times 5$ mekik koşu testi değeri aktif spor yapmayan erkek öğrencilere göre anlamlı $(p<0,05)$ olarak daha düşük bulunmuştur. Boy uzunluğu, vücut ağırlığı, vücut kitle indeksi, flamingo denge testi, disklere dokunma, otur-eriş, el pençe kuvveti, mekik ve bükülü kol asılma testi değerleri arasında aktif spor yapan erkek öğrenciler ile yapmayan erkek öğrenciler arasında anlamlı $(p>0,05)$ bir farklılık bulunamamıştır. 
Asma, MB., Iş̧1k, MA. (2020). Okul Sporlarına Katılan ve Katılmayan Ortaöğretim Öğrencilerinin Fiziksel Uygunluklarının Eurofit Test Bataryası ile Karşılaştırılması. Gaziantep Üniversitesi Spor Bilimleri Dergisi, 5(1), 10-26.

\section{Tartışma ve Sonuç}

Fiziksel uygunluk ölçümleri sonucu aktif spor yapan kız öğrencilerin otur-eriş, mekik testi, bükülü kol asılma testi, durarak uzun atlama ve 20 Metre mekik koşusu değerleri aktif spor yapmayan kız öğrencilere göre anlamlı olarak daha yüksek bulunurken, $10 \times 5$ mekik koşu testi, flamingo denge testi ve disklere dokunma testi değerleri aktif spor yapmayan kız öğrencilere göre anlamlı $(p<0.05)$ olarak daha düşük bulunmuştur. Boy uzunluğu, vücut ağırlığı, vücut kitle indeksi ve el pençe kuvveti değerleri arasında aktif spor yapan kız öğrenciler ile aktif spor yapmayan kız öğrenciler arasında anlamlı farklılık ( $p>0.05)$ bulunamamıştır.

Aktif spor yapan erkek öğrencilerin durarak uzun atlama, 20 Metre mekik koşu testi, mekik ve bükülü kol asılma değerleri aktif spor yapmayan erkek öğrencilere göre anlamlı olarak daha yüksek olduğu bulunurken $10 \times 5$ mekik koşu testi ve disklere dokunma test değerleri aktif spor yapmayan erkek öğrencilere göre anlamlı $(p<0.05)$ olarak daha düşük bulunmuştur. Boy uzunluğu, vücut ağırlığı, vücut kitle indeksi, flamingo denge testi, otur-eriş ve el pençe kuvveti değerleri arasında aktif spor yapan erkek öğrenciler ile yapmayan erkek öğrenciler arasında anlamlı farklılık ( $p>0.05)$ bulunamamıştır.

Koç (2014) 15-17 yaş kız grubunda yaptığı çalışmada 15 yaş grubunda vücut kitle indeksi ortalamasını 22,56 16 yaşta 22,90 17 yaşta 22,42 bulmuştur. Yaş grupları arasında anlamlı farklılık bulunamamıştır. Erkeklerde 15 yaş grubunda vücut kitle indeksi ortalamasını 21,57 16 yaşta 22,26, 17 yaşta 22,57 bulmuştur. Yaş grupları arasında anlamlı farklılık bulunamamıştır. Sayın (2014) 15-17 yaş kız grubunda yaptığı çalışmada vücut kitle indeksi ortalamasını 21,20 bulmuştur. Erkeklerde 15-17 yaş grubunda vücut kitle indeksi ortalamasını 21,48 bulmuştur.Bilim (2013) 16-17 yaş erkeklerde spor yapan öğrencilerin vücut kitle indeksi ortalamasını 22,56 bulmuştur. Spor yapmayanların vücut kitle indeksi ortalamasını 22,98 bulmuştur. Anlamlı farklılık bulunamamıştır.

Vücut kitle indeksine ait bulgular ve literatür değerlendirildiğinde, elde ettiğimiz sonuçlarla paralellik gösteren çalışmalara rastlanmaktadır. WHO (2007) verilerine göre 15-16 yaş kızlarda VKI değerleri 50. Percentilde 20,6 17-18 yaş kızlarda ise 21,2 bulunmuştur. Erkeklerde ise 15-16 yaşta 20,5 17-18 yaşta 21,6 bulunmuştur. Çalışmamızda bulunan ortalama VKI değerleri ile who referans değerleri benzerlik 
Asma, MB., Iş̧1k, MA. (2020). Okul Sporlarına Katılan ve Katılmayan Ortaöğretim Öğrencilerinin Fiziksel Uygunluklarının Eurofit Test Bataryası ile Karşılaştırılması. Gaziantep Üniversitesi Spor Bilimleri Dergisi, 5(1), 10-26.

taşımaktadır. Spor yapanların VKI değerlerinin yapmayanlara oranla genelde daha düşük olduğu görülmüştür.

Bilim (2013) 16-17 yaş kız grubunda yaptığı çalışmada spor yapan kız öğrencilerin flamingo denge testi hata ortalamasını 8,00 ve spor yapmayan kızların flamingo denge testi hata sayısı ortalamasını 11,18 bulmuştur. Anlamlı farklılık bulunamamıştır. Bilim (2013) 16-17 yaş erkek grubunda yaptığı çalışmada spor yapan erkek öğrencilerin flamingo denge testi hata ortalaması 7,06 ve spor yapmayan erkeklerin flamingo denge testi hata ortalaması 10,38 bulmuştur. Anlamlı farklılık bulunamamıştır. Tomkinson ve arkadaşları (2017) Avrupa'da adölesanlar üzerine yapılmış çalışmaları derleyip 2.779.165 kişinin normatif değerlerini ortaya koymuşlardır. Çalışma sonucunda flamingo denge testinde 15-16-17 yaş erkek çocuklarının 50.nci persentile rast gelen değer ortalamasında 10 hata sayısına ulaşılmıştır. Kızlarda 15 yaş grubunda 50.nci persentilde 10 hata ortalamasına, 16-17 yaş grubunda ise 9 hata ortalamasına ulaşılmıştır.

Flamingo denge testine ait bulgular ve literatür değerlendirildiğinde, elde ettiğimiz sonuçlarla paralellik gösteren çalışmalara rastlanmakla birlikte, farklılık gösteren çalışmalarda gözlenmiştir. Yapılan araştırmalarda, aktif spor yapan öğrencilerin flamingo denge testi sonuçları aktif spor yapmayanlara oranla daha iyi olduğu görülmektedir. Araştırmamızda Tomkinson ve arkadaşlarının yapmış olduğu çalışmada bulunan ortalama değerlere yakın sonuçlar bulunmuş olup farklıı̆ın nedeni yapılan spor branşı ve güdülenmenin zayıf olmasından kaynaklanabilir. Çalık ve arkadaşları (2019) 14 haftalık IAAF çocuk atletizm antrenmanlarının flamingo denge testi değerlerini geliştirdiği sonucuna ulaşmışlardır. Bayraktar (2005) tez çalışmasında 11-12 yaş yüzme, jimnastik ve atletizm sporcularının fiziksel ve motorsal özelliklerini karşılaştırmış olup cimnastik sporu yapanların denge değerlerini diğer sporları yapanlara göre yüksek bulmuştur. Spor yapmanın dengenin gelişimine katkı sağladığı söylenebilir.

Bilim (2013) 16-17 yaş kız grubunda yaptığı çalışmada spor yapan kızların disklere dokunma test süresi ortalamasını 11,63 sn. ve spor yapmayan kızların disklere dokunma test süresi ortalamasını 12,71 sn. bulmuştur. Anlamlı farklılık bulunamamıştır. Bilim (2013) 14-15 yaş erkek grubunda yaptığı çalışmada spor yapan erkeklerin disklere dokunma test süresi ortalamasını $11,87 \mathrm{sn}$. ve spor 
Asma, MB., Iş̧1k, MA. (2020). Okul Sporlarına Katılan ve Katılmayan Ortaöğretim Öğrencilerinin Fiziksel Uygunluklarının Eurofit Test Bataryası ile Karşılaştırılması. Gaziantep Üniversitesi Spor Bilimleri Dergisi, 5(1), 10-26.

yapmayan erkeklerin disklere dokunma test süresi ortalamasını 13,87 sn. bulmuştur.Anlamlı farklılık bulunmuştur.

Pense ve Serpek (2010) 14-16 yaş basketbol oynayan ve oynayamayan kız öğrenciler üzerinde yaptıkları araştırmada basketbol oynayan kızların disklere dokunma test süresi ortalamasını 118,03 sn. basketbol oynamayanların ortalamasını ise 123,66 sn. bulmuştur. Anlamlı farklılık bulunamamıştır. Tomkinson ve arkadaşları (2017) yaptıkları çalışma sonucunda disklere dokunma testinde 15, 16, 17 yaş erkek çocuklarının 50.nci persentile rast gelen değerleri 15 yaşta 11,14 sn. 16 yaşta 10,74 sn. 17 yaşta 10,56 sn. olarak bulunmuştur. Kızlarda 50 .nci persentilde 15 yaşta 11,91 sn. 16 yaşta 11,73 sn. 17 yaşta 11,71 sn. bulunmuştur. Dobosz ve arkadaşları (2015) Polonya'da 7-19 yaş grubunda 25,687 erkek ve 23,594 kız üzerinde fiziksel uygunluk çalışması yapmıştır. Çalışma sonucunda erkeklerde disklere dokunma testinde 50.nci persentile rast gelen değerler 15yaş erkeklerde 10,2 sn. 16 yaş erkeklerde 9,9 sn. 17 yaş erkeklerde 9,7 sn. 18 yaş erkeklerde 9,6 sn. bulunmuştur. Kızlarda 50.nci persentile rast gelen değerler 15 yaşta $11,7 \mathrm{sn}$. 16 yaşta $11,7 \mathrm{sn} .17$ yaşta $11,7 \mathrm{sn}$. ve 18 yaşta 11,6 sn. sonucuna ulaşılmıştır. Disklere dokunma testine ait bulgular ve literatür değerlendirildiğinde, elde ettiğimiz sonuçlarla paralellik gösteren çalışmalara rastlanmakla birlikte, farklıık gösteren çalışmalarda gözlenmiştir. Yapılan araştırmalarda, aktif spor yapan öğrencilerin disklere dokunma test sonuçları aktif spor yapmayanlara oranla daha iyi olduğu görülmektedir. Araştırmamızda tüm yaş gruplarında Tomkinson ve Dobosz' un yapmış olduğu çalışmada bulunan ortalama değerlerden daha iyi sonuçlara ulaşılmıştır. Şirinkan (2011) 7-12 yaş aralığındaki çocuklarda 16 haftalık futbol çalışması sonucunda disklere dokunma testinde anlamlı farklıık tespit etmiştir. Aktif spor yapmanın el çabukluğunu arttırdığı, antrenman ve spor müsabakaların da bu duruma katkı sağladığı söylenebilir.

Atlı (2009) yaptığı çalışmada otur-eriş testi sonuçlarını basketbolcularda 24,80 cm, futbolcularda 18,25 cm, sedanterlerde 15,65 cm olarak tespit etmiştir. Elde edilen sonuçlardan aktif spor yapanlar ve yapmayanlar arasında esneklik açısından anlamlı farklılık $(p<0,05)$ olduğunu göstermektedir. Kılıçaslan (2015)Trabzon Spor Lisesi ile diğer lise öğrencilerinin otur-eriş test dereceleri arasında anlamlı fark $(p<0,05)$ bulmuştur. Trabzon Spor Lisesi öğrencilerinin otur-eriş test dereceleri 17,12 cm iken diğer liselerde öğrenim gören öğrencilerin otur-eriş test dereceleri $8,59 \mathrm{~cm}$ bulunmuştur. Pense ve Serpek (2010) 14-16 yaş grubundaki kadın basketbolcuların 
Asma, MB., Iş̧1k, MA. (2020). Okul Sporlarına Katılan ve Katılmayan Ortaöğretim Öğrencilerinin Fiziksel Uygunluklarının Eurofit Test Bataryası ile Karşılaştırılması. Gaziantep Üniversitesi Spor Bilimleri Dergisi, 5(1), 10-26.

otur-eriş test derecelerini $28,14 \mathrm{~cm}$, basketbol oynamayanlarda ise $24,01 \mathrm{~cm}$ olarak belirlemiş ve anlamlı farklılık $(p<0,05)$ olduğunu belirtmiştir. Tomkinson ve arkadaşları (2017) yaptıkları çalışma sonucunda otur-eriş testinde $15,16,17$ yaş erkek çocuklarının 50.nci persentile rast gelen değerleri 15 yaşta $20,3 \mathrm{~cm} 16$ yaşta $21,4 \mathrm{~cm}$ 17 yaşta 22,6 cm olarak ölçülmüştür. Kızlarda 50.nci persentilde 15 yaşta 25,4 cm 16 yaşta $25,9 \mathrm{~cm} 17$ yaşta $26,1 \mathrm{~cm}$ ölçülmüştür.

Otur-eriş testine ait bulgular ve literatür değerlendirildiğinde, elde ettiğimiz sonuçlarla paralellik gösteren çalışmalara rastlanmakla birlikte, farklılık gösteren çalışmalarda gözlenmiştir. Araştırmamızda tüm yaş gruplarında Tomkinson ve arkadaşlarının yapmış olduğu çalışmada bulunan ortalama değerlere yakın sonuçlara ulaşılmıştır. Düzgün ve Baltacı (2009) çalışmasında düzenli spor yapmanın esnekliğin gelişimini arttırdığını ve bu gelişimin en fazla spor yapan kızlarda olduğu sonucuna varılmıştır. Çalışmamızın sonucunda düzenli spor yapmanın esnekliğe katkı sağlayıp gelişimine etkisi olduğunu, bu gelişimin en fazla aktif spor yapan kızlarda olduğu görülmüştür. 13-18 yaş dönemde esnekliğin geliştirilmesi için ilk yapılması gerekenlerden biri de düzenli olarak esnetme egzersizleri yapılmasıdır.

Bilim (2013) 16-17 yaş erkek grubunda yaptığı çalışmada spor yapan erkeklerin durarak uzun atlama test ortalamasını 186,18 cm ve spor yapmayan erkeklerin durarak uzun atlama test ortalamasını 161,11 cm bulmuştur. Anlamlı farklılık $(p<0,05)$ bulunmuştur. Kılıçaslan (2015)Trabzon Spor Lisesi ile diğer lise öğrencilerinin durarak uzun atlama test sonuçları arasında anlamlı fark $(p<0,05)$ bulmuştur. Spor Lisesi öğrencilerinin durarak uzun atlama test ortalaması 204,71 cm, diğer lise öğrencilerinin durarak uzun atlama test ortalaması 168,85 cm bulunmuştur. Pense ve Serpek (2010) 14-16 yaş grubundaki kadın basketbolcuların durarak uzun atlama test ortalamasını $175,10 \mathrm{~cm}$, basketbol oynamayanlarda ise $152,71 \mathrm{~cm}$, olarak belirlemiş ve bu farklılıkların anlamlı $(p<0,05)$ olduğu belirlenmiştir. Durarak uzun atlama testine ait bulgular ve literatür değerlendirildiğinde, elde ettiğimiz sonuçlarla paralellik gösteren çalışmalara rastlanmakla birlikte, farklılık gösteren çalışmalarda gözlenmiştir. Araştırmamızda tüm yaş gruplarında Tomkinson ve arkadaşlarının yapmış olduğu çalışmada bulunan ortalama değerlere yakın sonuçlara ulaşılmış olup Dobosz ve arkadaşlarının yaptığı çalışmayla karşılaştırıldığında ise daha düşük değerlere ulaşılmıştır. Yörükoğlu ve Koz (2007) 5 ay süreyle basketbol antrenmanı yapan sporcuların durarak uzun atlama testlerinde ön test ve son test 
Asma, MB., Iş̧1k, MA. (2020). Okul Sporlarına Katılan ve Katılmayan Ortaöğretim Öğrencilerinin Fiziksel Uygunluklarının Eurofit Test Bataryası ile Karşılaştırılması. Gaziantep Üniversitesi Spor Bilimleri Dergisi, 5(1), 10-26.

ölçümleri arasında anlamlı farklııı $(p<0,05)$ tespit edilmiştir. Çalışmamızda aktif spor yapanların içinde atletizm branşını yapan sporcuların fazla olmasının da değerlerin yüksek çıkmasına etkisi olduğu düşünülmektedir. Durarak uzun atlama derecelerinin yüksek olmasında kişinin boyunun uzun olmasının da etkisi vardır. Yapılan sporun türüne göre boy uzunluğu önem arz etmektedir. Koç ve Aslan (2010) erkek hentbol ve voleybol sporcularının seçilmiş fiziksel ve motorik özelliklerinin karşıllaştııılması çalışmasında durarak uzun atlama testinde voleybolcular lehine farklılık bulunmuştur. Basketbol ve voleybol sporu genellikle boy uzunluğunun pozitif üstünlük sağladığı sporların başında gelir. Bu sporlarla ilgilenen kişilerle durarak atlama derecelerinin yüksek çıkması beklenmektedir.

El pençe kuvveti testine ait bulgular ve literatür değerlendirildiğinde, elde ettiğimiz sonuçlarla paralellik gösteren çalışmalara rastlanmakla birlikte, farklılık gösteren çalışmalarda gözlenmiştir. El pençe kuvveti test sonuçlarına göre spor yapan ve yapmayan öğrenciler arasında anlamlı farklıık bulunamamıştır. 17-18 yaş kız ve erkek gruplarında yaptığımız çalışmada pençe kuvveti ortalamaları Bilim, Kürkçü, Kürkçü ve Aydos'un çalışmalarına göre daha yüksek bulunmuştur. Araştırmamızda tüm yaş gruplarında Tomkinson ve arkadaşlarının yapmış olduğu çalışmada bulunan ortalama değerlere yakın sonuçlara ulaşıımış olup Dobosz ve arkadaşlarının yaptığı çalışmayla karşılaştıııldığında ise kızlarda benzer sonuçlara erkeklerde ise daha düşük değerlere ulaşılmıştır. Van bölgesinin diğer çalışma yapılan illere oranla daha kırsal olması ve öğrencilerin beden gücü gerektiren işlerde çalışmasının bu sonucu doğurduğu düşünülmektedir.

Kılıçaslan (2015)Trabzon Spor Lisesi ile diğer lise türlerindeki öğrencilerin mekik testi sonuçları arasında anlamlı farklılık $(p<0,05)$ bulmuştur. Trabzon spor lisesi öğrencilerinin mekik sayısı ortalaması 29,59 diğer liselerdeki öğrencilerin mekik sayısı ortalaması 19,84 bulunmuştur. Bilim ve Çetinkaya (2016) 12-13, 14-15, 16-17 yaş spor yapan erkek ve spor yapmayan erkeklerde mekik testi değerlerinde anlamlı farklılık $(p<0,05)$ bulmuşlardır. 12-13 yaş spor yapan erkeklerde mekik değerleri 25,61 ortalamaya sahip iken spor yapmayanlar ise 18,52 ortalamaya sahiptir. 14-15 yaş spor yapan erkeklerde mekik değerleri 23,97 spor yapmayan erkeklerde ise 21,21 bulunmuştur. 16-17 yaş spor yapan erkeklerde mekik değerleri 30,29 spor yapmayan erkeklerde ise 21,56 bulunmuştur. Yaş gruplarının tamamında anlamlı farklılık $(p<0,05)$ vardır. Pense ve Serpek (2010) 14-16 yaş basketbol oynayan ve 
Asma, MB., Iş̧1k, MA. (2020). Okul Sporlarına Katılan ve Katılmayan Ortaöğretim Öğrencilerinin Fiziksel Uygunluklarının Eurofit Test Bataryası ile Karşılaştırılması. Gaziantep Üniversitesi Spor Bilimleri Dergisi, 5(1), 10-26.

oynayamayan kız öğrenciler üzerinde yaptıkları araştırmalarında mekik testi değerleri arasında anlamlı farklılık $(p<0,05)$ bulmuşlardır. Basketbol oynayanlarda mekik ortalaması 20,00 oynamayanlarda 15,61 değerlerine ulaşılmıştır. Tomkinson ve arkadaşları (2017) yaptıkları çalışma sonucunda mekik testi 15,16,17 yaş erkek çocuklarının 50.nci persentile rast gelen değerleri 15 yaşta 24,16 ve 17 yaşta 25 olarak bulunmuştur. Kızlarda 50.nci persentilde 15,16,17 yaşta 20 ortalama bulunmuştur.

Mekik testine ait bulgular ve literatür değerlendirildiğinde, elde ettiğimiz sonuçlarla paralellik gösteren çalışmalara rastlanmaktadır. Araştırmamızda tüm yaş gruplarında Tomkinson ve arkadaşlarının yapmış olduğu çalışmada bulunan ortalama değerlerden daha düşük değerlere ulaşılmıştır. Pancar ve arkadaşları (2018) mekik testinde deney grubu ve kontrol grubu arasında anlamlı farklılık $(p<0,05)$ bulmuştur. Spor yapmanın karın kası dayanıklııı̆ını artırdığı söylenebilir. Yapılan spor branşına göre karın kası dayanıklıığının farklıık göstereceği de bilinmektedir.

Bilim (2013) 14-15 yaş kız grubunda yaptığı çalışmada spor yapan kızların bükülü kol asılma test sonuçları ortalaması 11,42 sn. ve spor yapmayan kızların ortalamasını 7,26 sn. bulmuştur. Anlamlı farklıık $(p<0,05)$ bulunmuştur. 14-15 yaş erkek grubunda yaptığı çalışmada spor yapan erkeklerin bükülü kol asılma test sonuçları ortalamasını 25,56 sn. ve spor yapmayanların ortalamasını 14,63 sn. bulmuştur. Anlamlı farklıık $(p<0,05)$ bulunmuştur. Pense ve Serpek (2010) 14-16 yaş basketbol oynayan ve oynayamayan kız öğrenciler üzerinde yaptıkları araştırmalarında bükülü kol asılma testi değerleri arasında anlamlı farklılık $(p>0,05)$ bulamamışlardır. Basketbol oynayanlarda bükülü kol asılma testi değerleri 13,30 sn. oynamayanlarda 10,11 sn. değerlerine ulaşılmıştır. Saraç (2012) 12-15 yaş erkek grubu üzerinde yaptığı çalışmada deney grubunun antrenman öncesi bükülü kol asılma test ortalamasını 42,20 sn. antrenman sonrası 40,80 sn. bulmuştur. Deney gurubunun antrenman öncesi bükülü kol asılma testi ve antrenman sonrası bükülü kol asılma test ölçümleri arasında anlamlı farklııık $(p>0,05)$ bulunamamıştır.

Bükülü kol asılma testine ait bulgular ve literatür değerlendirildiğinde, elde ettiğimiz sonuçlarla paralellik gösteren çalışmalara rastlanmakla birlikte, farklılık gösteren çalışmalarda gözlenmiştir. Uyguladığımız testlerde bükülü kol asılma testinde 17-18 yaş erkek ve17-18 yaş kız grubunda spor yapanların değerleri yapmayanlara oranla daha yüksektir. Kumartaşı ve arkadaşları (2014) 10-12 yaş 
Asma, MB., Iş̧1k, MA. (2020). Okul Sporlarına Katılan ve Katılmayan Ortaöğretim Öğrencilerinin Fiziksel Uygunluklarının Eurofit Test Bataryası ile Karşılaştırılması. Gaziantep Üniversitesi Spor Bilimleri Dergisi, 5(1), 10-26.

grubunda bükülü kol asılma testinde deney ve kontrol grubu arasında anlamlı farklılık testpit etmişlerdir. Araştırmamızda tüm yaş gruplarında Tomkinson ve arkadaşlarının yapmış olduğu çalışmada bulunan ortalama değerlerden daha yüksek değerlere ulaşılmıştır. Bayraktar (2005) tez çalışmasında 11-12 yaş yüzme, jimnastik ve atletizm sporcularının fiziksel ve motorsal özelliklerini karşılaştıııması çalışmasında atletizm sporu yapanların bükülü kol asılma test değerleri diğer sporları yapanlara göre yüksek bulunmuştur. Yapılan spor branşının da test sonuçlarında farklıı̆a neden olacağı bilinmelidir. Spor yapmanın göğüs ve omuz kaslarının gelişimini etkilediği söylenebilir.

Bilim (2013) 16-17 yaş kız grubunda yaptığı çalışmada spor yapan kız öğrencilerin 10x5 mekik koşusu testi ortalamasını 23,28 sn. ve spor yapmayanların kızların ortalamasını 24,87 sn. bulmuştur. Anlamlı farklılık $(p<0,05)$ bulunmuştur. 1617 yaş erkek grubunda yaptığı çalışmada spor yapan erkek öğrencilerin 10x5 mekik koşusu testi ortalaması 21,40 sn. ve spor yapmayan erkeklerin ortalaması 23,63 sn. bulmuştur. Anlamlı farklıık $(p<0,05)$ bulunmuştur. Pense ve Serpek (2010) 14-16 yaş basketbol oynayan ve oynayamayan kız öğrenciler üzerinde yaptıkları araştırmalarında 10x5 mekik koşu testi değerleri arasında anlamlı farklıık ( $p>0,05$ )bulamamışlardır. Basketbol oynayanlarda 10x5 mekik koşu testi değerleri 22.28 sn. oynamayanlarda 23.95 sn. ölçülmüştür. Tomkinson ve arkadaşları (2017) yaptıkları çalışma sonucunda $10 \times 5$ mekik koşu testi $15,16,17$ yaş erkek çocuklarının 50.nci persentile rast gelen değerleri 15 yaşta 20,05 sn 16 yaşta 19,73 sn 17 yaşta 19,45 sn olarak bulunmuştur. Kızlarda 50 .nci persentilde 15 yaşta 22,00 sn 16 yaşta 21,98 sn 17 yaşta 21,96 sn bulunmuştur.10x5 mekik koşu testine ait bulgular ve literatür değerlendirildiğinde, elde ettiğimiz sonuçlarla paralellik gösteren çalışmalara rastlanmakla birlikte, farklıık gösteren çalışmalarda gözlenmiştir. Uyguladığımız testlerde 10x5 mekik koşusu testinde 15-16, 17-18 yaş erkek ve15-16, 17-18 yaş kız grubunda spor yapanların değerleri yapmayanlara oranla daha yüksektir. Koçak ve Kartal (2003) erkek ve kız öğrencilerin ön test ve son test ölçümleri arasında 10x5 mekik koşusunda anlamlı farklılık $(p<0,05)$ bulmuştur. Araştırmamızda tüm yaş gruplarında Tomkinson ve ark., (2017) yapmış olduğu çalışmada bulunan ortalama değerlerden daha yüksek değerlere ulaşılıı̧tır. Yapılan spor branşının da test sonuçlarında farklıı̆a neden olacağı bilinmelidir. Spor yapmanın sürati ve çevikliği arttırdığı kaslarının gelişimini etkilediği söylenebilir. 
Asma, MB., Iş̧1k, MA. (2020). Okul Sporlarına Katılan ve Katılmayan Ortaöğretim Öğrencilerinin Fiziksel Uygunluklarının Eurofit Test Bataryası ile Karşılaştırılması. Gaziantep Üniversitesi Spor Bilimleri Dergisi, 5(1), 10-26.

Bilim (2013) 12-13, 16-17 yaş spor yapan erkekler ve spor yapmayan erkeklerde 20 metre mekik koşusu test değerlerinde anlamlı farklılık $(p<0,05)$ bulmuştur. 14-15 yaş spor yapan erkeklerde 20 metre mekik koşusu testinde anlamlı farklılık ( $p>0,05)$ bulunamamıştır. 12-13 yaş erkeklerin 20 metre mekik koşusu test ortalaması 39,60 iken spor yapmayanlarda ise 31,95'dir. 14-15 yaş spor yapan erkeklerde 20 metre mekik koşusu değerleri 34,15 spor yapmayan erkeklerde ise 34,94 bulunmuştur. 16-17 yaş spor yapan erkeklerde 20 metre mekik koşusu değerleri 44,89 spor yapmayan erkeklerde ise 33,43 bulunmuştur. Polat ve ark.(2003) 15 yaş çocuklarının fiziksel uygunluk düzeylerinin incelenmesi çalışmasında aktif spor yapan erkekler ile sedanterlerin 20 metre mekik koşusu testi değerlerinde anlamlı farklılık $(p<0,05)$ bulmuşlardır. Futbol sporunu yapanlarda ortalama 43,29, fitness sporunu yapanlarda 45,57, sedanterlerde 37,56 sonucuna ulaşılmıştır. Dobosz ve arkadaşları (2015) yaptıkları çalışma sonucunda 20 metre mekik koşusu testinde 15,16,17,18 yaş erkek çocuklarının 50.nci persentile rast gelen değerleri 15 yaşta 55 tekrar 16 yaşta 57 tekrar 17 yaşta 59 tekrar 18 yaşta 59 tekrar olarak bulunmuştur. Kızlarda 50 .nci persentilde 15 yaşta 34 tekrar 16 yaşta 33 tekrar 17 yaşta 32 tekrar 18 yaşta 31 tekrar olarak bulunmuştur..

20 metre mekik koşu testine ait bulgular ve literatür değerlendirildiğinde, elde ettiğimiz sonuçlarla paralellik gösteren çalışmalara rastlanmakla birlikte, farklılık gösteren çalışmalarda gözlenmiştir. Uygulanan testlerde 20 metre mekik koşusu testinde spor yapanların değerleri yapmayanlara oranla daha yüksektir. Atletizm sporu ile ilgilenen kişilerde aerobik güç parametrelerinde artış olacağı bilinmektedir. Çalışmamızda atletizm sporunu yapanların oranının yüksek olması, sonuçları pozitif yönde etkilediği düşünülmektedir. Kaya ve Gökdemir (2015) yaptıkları çalışmada Yüksek irtifada yapılan antrenmanlar özellikle aerobik aktiviteleri olumlu yönde etkilediği sonucuna ulaşmışlardır. Testlerin yapıldığı il olan Van'ın rakımının 1730 olmasının da test değerlerinde artışa neden olduğunu kanıtlar niteliktedir. Spor yapmanın aerobik dayanıklılığı arttırdığı söylenebilir.

Sonuç olarak, 15-18 yaş aktif spor yapan erkek ve kız öğrencilerin eurofit fiziksel uygunluk test bataryası sonuçları aktif spor yapmayanlara oranla daha yüksek bulunmuştur. Bu durum okul takımlarında lisanslı olarak spor yapmanın fiziki gelişimi desteklediğini göstermektedir. Eurofit test bataryasının; sporcuların performansının belirlenmesi, velilere çocuklarının gelişimi hakkında bilgi vermesi, eğitmenlere de 
yetenek seçiminde yol gösterici olmasından dolayı kullanılması fayda sağlayacaktır. Milli Eğitim Bakanlığı ile Sağlık Bakanlığı arasında imzalanan protokolde sağlık ile ilgili fiziksel uygunluk ve yine Milli Eğitim Bakanlığı ile Gençlik ve Spor Bakanlığı arasında imzalanan Beceri ile ilgili fiziksel uygunluk çalışmalarının tek elden yürütülmesini sağlamak amacıyla ortak bir çalışma yürütülebilir. Yapılacak ortak çalışmalarla zaman ve iş gücü kaybının önüne geçilmesi sağlanabilir. Tek elden veri akışının sağlanması, okul ve kulüplere gerekli ölçümler için, malzeme desteği sağlanması ölçümlerin yapılmasına katkı sağlayacaktır. Diğer önemli bir konuda eğiticilerin eğitimi konusunda eğitimler düzenlenmesi gerekmektedir. Ülkemizde çocukluk ve ergenlik dönemi fiziksel uygunluk düzeyini belirlemeye yönelik çalışmalar yeterli seviyede değildir. Amerika ve Avrupa da fiziksel uygunluk düzeylerini belirlemek amacıyla birçok test bataryası kullanılarak ülkelere özgü test bataryaları geliştirilmiş olup ülkeler kendi normlarını oluşturmaya başlamışlardır. Ülkemize özgü test bataryası geliştirilmesi ve bunun sonucunda fiziksel uygunluk normlarımızın oluşturulması sağlanmalıdır.

\section{Kaynaklar}

Atı, A. (2009). 14-16 yaşları arasındaki erkek basketbolcu, futbolcu, ve sedanterlerin bazı fiziksel, fizyolojik ve antropometrik özelliklerinin karşılaştırılması. Selçuk Üniversitesi: Yüksek Lisans Tezi.

Baltacı, G. ve Düzgün, İ. (2008). Adolesan ve egzersiz. Ankara:Klasmat Matbaacılık. Bayraktar, L. (2005). 11-12 yaş grubu yüzme, cimnastik ve atletizm sporcuları yapan bayan sporcuların fiziksel ve motorsal gelişim özelliklerinin karşılaştırılması. Marmara Üniversitesi: Yüksek Lisans Tezi.

Bilim, A. S. (2013). 12-17 yaş arası spor yapan ve spor yapmayan öğrencilerin fiziksel uygunluklarının incelenmesi. Dokuz Eylül Üniversitesi: Yüksek Lisans Tezi.

Bilim, A. S., Çetinkaya, C., Dayı, A. , (2016). 12-17 yaş arası spor Yapan ve yapmayan öğrencilerin fiziksel uygunluklarının incelenmesi. Spor ve Performans Araştırmaları Dergisi, 7, 53-60.

Çalık, S. U.,Kamiş, O., Pekel, A. H. ve Aydos, L. (2019). IAAF Çocuk atletizm programının ortaokul öğrencilerinin bazı fiziksel uygunluk testlerine etkisi. Gazi Beden Eğitimi ve Spor Bilimleri Dergisi, 24(1), 51-61. 
Demir, I. (2001). Beden Eğitimi Ve Sporun Beceri, Yetenek Gelişimlerine Etkisi 11-13 Yaş Grubunda Eurofit Test Değerlendirilmesi.Sakarya Üniversitesi: Yüksek Lisans Tezi.

Düzgün, İ. ve Baltacı, G. (2009). Düzenli spor yapan ve yapmayan adölesanlarda esneklik test sonuçlarının yaş ve cinsiyete bağlı değişimi. Fizyoterapi Rehabilitasyon Dergisi, 20(3),184-189.

Kaya, İ. ve Gökdemir, K. (2015). Yüksek irtifada yapılan antrenmanların kastamonu beden eğitimi ve spor yüksekokulu öğrencilerinin bazı fiziksel özellikleri ve çeşitli kan parametreleri üzerine kronik etkilerinin araştırılması. Sportif Bakış: Spor ve Eğitim Bilimleri Dergisi, 2 (2), 79-86

Kayıhan, G. ve Ersöz, G. (2010). Türk polis teşkilatında vücut kompozisyonunun fiziksel uygunluk ve performans açısından değerlendirilmesi. Polis Bilimleri Dergisi, 12 (3), 67-82.

Kılıçaslan, U. (2015). Spor lisesi ile diğer liselerde öğrenim gören öğrencilerin bazı motorik özelliklerinin karşıllaşııılması. Karadeniz Teknik Üniversitesi: Yüksek Lisans Tezi.

Koç, K. (2014). Ortaöğretim öğrencilerinin fiziksel aktivite ve fiziksel uygunluk düzeylerinin incelenmesi. Erciyes Üniversitesi: Yüksek Lisans Tezi.

Koç, H. ve Aslan, C. S. (2010). Erkek hentbol ve voleybol sporcularının seçilmiş fiziksel ve motorik özelliklerinin karşılaştırılması. Selçuk Üniversitesi Beden Eğitimi ve Spor Bilim Dergisi, 12 (3), 227-231.

Kumartaşlı, M., Topuz, R. ve Dağdelen, S. (2014). 10-12 Yaş Grubu Futbolcuların Motorik Performansının Değerlendirilmesi. International Journal of ScienceCultureandSport. 2,101-113.

Pancar, Z., Biçer, M. ve Özdal, M. (2018). 12 - 14 yaş kadın hentbolculara uygulanan 8 haftalık pliometrik antrenmanların seçilmiş bazı kuvvet parametrelerine etkisi. Spor ve Performans Araştırmaları Dergisi, 9 (1), 18-24.

Pekel, H. A., Bağcı, E., Atalay, N., Onay, M., Serdar, Ş. ve Pepe, H. (2006). Spor yapan çocuklarda performansla ilgili fiziksel uygunluk test sonuçlarıyla antropometrik özellikler arasındaki ilişkilerin değerlendirilmesi. Kastamonu Eğitim Dergisi, 1, 299-308. 
Pense, M. ve Serpek, B. (2010). 14-16 yaş arası basketbol oynayan kız öğrencilerin fizyolojik ve biyomotorik özelliklerinin eurofit test bataryası ile belirlenmesi. Selçuk Üniversitesi Beden Eğitimi ve Spor Bilim Dergisi, 12 (3), 191-198.

Polat, Y., Çınar, V., Kesler, A., Adıgüzel, R. (2003). 15 yaş çocuklarının fiziksel uygunluk düzeylerinin incelenmesi. İstanbul ÜniversitesiSpor Bilim Dergisi, 11(3), 109-113.

Saraç, H. (2012). Futbol branşında 12-15 yaş grubu erkek çocukların fiziksel gelişiminin eurofit test bataryasıyla değerlendirilmesi. Erciyes Üniversitesi: Yüksek Lisans Tezi.

Sayın, N. (2014). 15-17 Yaş grubu gençlerin fiziksel aktivite düzeyleri ile fiziksel uygunlukları arasındaki ilişki. Selçuk Üniversitesi: Yüksek Lisans Tezi.

Şirinkan, A. (2011). 7-12 yaş grubu futbol okulu öğrencilerinin, fiziksel uygunluklarııın eurofit testleriyle incelenmesi (Erzurum ili örneği). e-Journal of New World Sciences Academy, 6 (3), 178-184

Tomkinson, Grant, R.,Kevin, D. Carver., Frazer, Atkinson. (2017). European normative values for physical fitness in children and adolescents aged 9-17 years: resultsfrom 2779165 Eurofit performances representing 30 countries. British Journal of Sports Medicine, 10, 1-13.

World Health Organization(WHO) (2019). [https://www.who.int/growthref/ who2007_bmi_for_age/en/]. Erişim Tarihi: 06 Mayıs 2019.

Yörükoğlu, U. ve Koz, M. (2007). Spor okulu çalışmaları ile basketbol antrenmanlarının 10-13 yaş grubu erkek çocukların fiziksel, fizyolojik ve antropometrik özelliklerine etkisi. Spormetre Beden Eğitimi ve Spor Bilimleri Dergisi, 5 (2), 79-83. 